\title{
A EMANCIPAÇÃO DO ADMINISTRADOR MERCADOLÓGICO
}

RAIMAR RICHERS

Após dez séculos de subordinação administrativa, o dirigente comercial da emprêsa se libera de um preconceito social, o que abre novos horizontes e o obriga a ampliar a sua esfera de atividade.

Estamos entrando numa fase de evolução mercantil, em que a sobrevivência da emprêsa depende, em grau crescente, da sua capacidade de adaptação aos mercados consumidores. Nos países altamente industrializados do Ocidente, esta transição da economia da produção para a economia do consumo já se tornou evidente; nos países semidesenvolvidos está deixando os seus primeiros marcos nítidos.

O Brasil é um exemplo disso. Entre nós, muitas emprêsas que, ainda há pouco, vendiam, sem grande esfôrço, o que conseguiam produzir, são hoje obrigadas a se dedicar intensamente ao problema da promoção de seus produtos. Dos ramos de negócios que mais estão sendo afetados pela transição convém citar, como exemplos, a indústria têxtil, a indústria automobilística, a indústria de aparelhos comésticos, a indústria de cigarros, a aviação comercial, as atividades bancárias e o comércio varejista em algumas regiões.

E natural que uma transição desta natureza e intensidade seja acompanhada por repercussões irternas na emprêsa, que forçam o administrador a alter? ces suas ações e atitu-

RAIMAR RICHERS - Professor Adjunto, Departamento de Mercadologia, e Chefe do Centro de Pesquisas e Publicações da Escola de Administração de Emprêsas de São Paulo. 
R.A.E.

des. Também isto se verifica no Brasil de hoje; gradativamente, o nosso administrador está abandonando a improvisação em favor do planejamento. Ao mesmo tempo, os pesos relativos das posições de chave estão sendo reavaliados nas emprêsas, frequientemente a favor do administrador mercadológico, diretor comercial, gerente de vendas, ou qualquer que seja o título oficial dos que respondem pelas vendas na emprêsa.

Ao que parece, o processo de transição acima referido provém de longa data, mas sòmente agora se está fazendo sentir com todo o seu poder, acumulado durante séculos.

Com o intuito de caracterizar êsse processo e para podermos melhor compreender a situação em que se encontra o administrador mercádológico da segunda parte do século 20 , analisaremos brevemente a história econômica, do ponto de vista da transição. Ao adotar êsse processo de interpretação histórica, esperamos poder dar respostas objetivas às seguintes perguntas:

Que se deve entender por "Mercadologia" e "mercadização"?

Que distingue a Mercadologia das vendas?

Que significa esta distinção para o administrador de emprêsas dentro de uma economia em expansão (como a do Brasil)?

\section{Um Conceito Controvertido}

Ao traduzir o conceito norte-americano "Marketing", a Escola de Administração de Emprêsas de São Paulo optou por um desdobramento da expressão em "Mercadologia" e "mercadização". Por Mercadologia entendemos o estudo sistemático da mercadização. Neste caso, o que vem a ser a mercadização?

De tôdas as definições de mercadização, a mais amplamente divulgada é a da American Marketing Association, ou seja: "Execução de atividades administrativas pertinentes ao fluxo 
de bens e serviços do produtor ao consumidor final, indus: trial ou comercial". (1)

$\mathrm{Na}$ época em que esta definição foi sugerida, muitos mercadólogos ainda estavam empenhados em achar uma justificação de ordem legal ou econômica para a mercadização, frisando, respectivamente, o aspecto da "transferência da posse" ou o ato da "criação de utilidade" envolvido no processo mercadológico. Em consequiência, a Mercadologia tendia a perder o contato com a realidade. Para evitar que isto acontecesse, a "Comissão de Definições da Associação Americana de Mercadologia" apresentou um conceito que "procura apenas descrever seu objeto em têrmos que possam ser compreendidos tanto pelos economistas profissionais, como pelos homens de negócios, sem implicações legais ou econôn micas". (2)

Dentro dêste espírito e objetivo, a Comissão encontrou, a nosso ver, uma definição bastante clara e precisa, que delineia, satisfatòriamente, o campo de atividade do homem de negócios responsável pelo setor de vendas na emprêsa.

Ultimamente, porém, surgiram sérias dúvidas quanto à conveniência desta definição. Alega-se que ela é demasiado técnica ou estática, por não dar a necessária ênfase ao aspecto promocional da criação de mercados que, hoje em dia, constitui a principal preocupação do administrador mercadológico nos países de concorrência acirrada. DRURY, por exemplo, argumenta que o problema da economia norte-americana não é o de superprodução de bens, mas o de subprodução de mercados. (3)

(1) Originalmente publicado em The Journal of Marketing, «Preliminary Report of the Definitions Committee of The American Marketing Association», R. S. Alexander, Chairman, vol. XIII, n. ${ }^{\circ}$, outubro de 1948, pág. 202 e seguintes.

(2) Op. cit., Comentário 3.

(3) James G. Drury, «Is your Problem Overproduction - or Underproduction of Markets ? », Printer's Ink, 5-7-1957, transcrito em E. J. Kelly e W. Lazer (editôres), Managerial Marketing: Perspectives and Viewpoints, Richard D. Irwin, Inc., Homewood, Ill., 1958, pág. 9 e seguintes. 
De fato, a definição da A.M.A. não inclui êste aspecto vital da mercadização, mas também não o exclui. Concordamos com HARRY L. HANSEN que a considera "perfeitamente aceitável", mas confessa não poder entusiasmar-se pelo conceito da Associação, "por lhe faltar o esprit do processo mercadológico" que PAUL MAZUR, com bastante humor e propriedade, caracterizou como "expedição de um padrão de vida". (4)

É de se esperar que uma definição amplamente satisfatória de Mercadologia ou mercadização só seja encontrada quando o próprio campo de ação do administrador mercadológico fôr mais claramente delineado, tanto em relação às funções que a emprêsa exerce no mercado, quanto em comparação com outras atividades intra-empresariais, tais como a produção, as finanças e a administração geral.

$\mathrm{Na}$ ausência desta "melhor" das definições, pergunta-se, lògicamente, se os têrmos tradicionais "comércio" e "vendas" não seriam mais adequados para indicar o tipo de atividade que se tem em mente, sobretudo porque os negócios prosperaram durante séculos, sem que o administrador tivesse que se preocupar com distinções de natureza "teórica" entre as suas atividades de compra e venda e aquilo que insistimos seja chamado de Mercadologia. No entanto, ambos os têrmos, comércio e vendas, têm conotações incompatíveis com o conceito da Mercadologia e, principalmente, com os princípios que êste envolve, face à situação inédita com que se defronta a emprêsa do século 20 .

Dos vários aspectos dessa nova situação, o que mais sobressai é a reestruturação dos altos cargos administrativos na emprêsa, em conseqüência de uma transformação de responsabilidades e atitudes do administrador, face aos problemas que surgem com a produção e distribuição em larga escala de bens altamente padronizados.

De todos os dirigentes empresariais, o administrador mercadológico é quem mais está sendo afetado por êste processo de transformação. Após vários séculos, em que o encarregado

(4) Harry L. Hansen, Marketing, Text, Cases and Readings, Richard D. Irwin, Inc., Homewood, Ill., 1956, pág. 6. 
do setor de vendas ocupou uma posição secundária, êste passa a se emancipar, tanto na organização interna da emprêsa, quanto na esfera social.

Passaremos a descrever, resumidamente, os diversos passos que levaram à emancipação do administrador mercadológico.

\section{As Origens do Desprêzo pelo Comércio}

Houve épocas, na primitiva história do Ocidente, em que o comércio foi a coluna vertebral para a economia de muitas comunidades. Contudo, no século 8 , as atividades comerciais sofreram um golpe mortal com a invasão dos islamitas na Europa e a decadência da navegação marítima. O europeu viu-se obrigado a procurar novos meios de vida; encontrou-os na agricultura. A terra passou a ser "a única fonte de riqueza". Tôdas as classes da população, desde o imperador, até o mais humilde de seus servidores, viviam, direta ou indiretamente, dos produtos do solo". (5) Criaram-se os latifúndios, mas perderam-se os mercados externos. Os poucos comerciantes eram os judeus, que se dirigiam a uma clientela restrita, composta, sobretudo, da aristocracia.

Sòmente "no decurso do século 10 reapareceu, na Europa continental, uma classe de comerciantes profissionais, cujo progresso, bem lento de início, tomou velocidade no avanço do próximo século." (6) Apesar de os pioneiros dêste movimento terem sido, na sua maioria, vagabundos e cavalheiros ladrões (os temidos Raubritter), foram êles os porta-bandeiras do renascimento econômico da Idade Média.

Socialmente, porém, os mercadores eram párias, invejados talvez, mas desrespeitados, tanto pelos nobres, quanto pela Igreja. "A nobreza nunca teve senão desprêzo por êsses novos

(5) Henri Pirenne, História Económica Y Social de La Edad Média, Fondo de Cultura Económica, México, Buenos Aires, Sexta Edição, 1955, pág. 12.

(6) Henri Pirenne, Medieval Cities, Their Origins and the Revival of Trade, Doubleday \& Company; Inc., Garden City், N.· Y., 1956, pág. 80. 
ricos, surgidos do desconhecido, cujas insolentes boas fortunas não podia suportar"... "Quanto ao clero, a atitude em relação aos comerciantes era ainda mais desfavorável. Aos olhos da Igreja, a vida comercial era perigosa à segurança da alma".. "Aos canonistas o comércio parecia ser uma forma de usura. Condenavam éles a procura do lucro, confundindo-a com a avareza." (7)

Tivemos, então, uma situação de conflito nesta época de recuperação econômica da Idade Média. De um lado, o comércio constituiu o elixir revitalizador do processo; do outro, o comerciante foi marcado pelo desdém alheio. E neste conflito e nas suas repercussões que, provàvelmente, poderemos encontrar as raízes de um preconceito que obstruiu o franco desenvolvimento mercantil no passado e ainda hoje afeta a posição social do comerciante.

\section{As Economias Fechadas da Idade Média}

Do século 12 em diante, uma nova camada social se estabelece: a classe média. O seu campo de ação é, por excelência, o burgo; a sua ocupação predileta a manufatura.

Quatro são os fatôres que determinam a relação produçãocomércio na Idade Média:

1. O elevado grau de auto-suficiência das cidades.

2. A produção sob encomenda.

3. A identidade produtor-comerciante.

4. A ausência do propósito de lucro.

Expliquemos brevemente o que devemos entender por êsses fatôres.

1. Com exceção da Hansa alemã, "não se pode falar na Idade Média de uma política mercantil das cidades". (8) 0 crescente progresso do artesanato torna o intercâmbio entre centros de consumo antieconômico e até supérfluo. As trocas mercantis restringem-se quase que sòmente às feiras, nas quais

(7) Op. cit., pág. 87 .

(8) Max Weber, História Económíca General, Fondo de Cultura Económica, México, Buenos Aires, Segunda Edição, 1956, pág. 205. 
artesãos e camponeses (que trabalham os campos em volta às cidades) oferecem uma parcela da sua produção.

2. A maioria dos bens, porém, é produzida sob encomenda. Quem necessita de um par de sapatos (ou qualquer outro produto manufaturado) procura a sua "oficina" predileta e manda fazê-lo sob medida. O contato direto entre produtor e consumidor torna a organização empresarial simples e eficiente. Os intermediários são desnecessários e o consumo é, em regra, assegurado sempre que persiste a boa qualidade.

3. Enquanto prospera êsse sistema, o artesão, como membro da guilda, é o dono absoluto de produção e comércio. Nêle se concentram tôdas as qualidades indispensáveis ao empresário da época: a capacidade técnica, a visão artística e a habilidade de ensino. Além do mais, o artesão "funciona como organizador e diretor da produção"... "mas é também o comerciante. Tôdas as atividades de compra e venda, tôda a organização da distribuição, em resumo, tudo aquilo que mais tarde é realizado com diligência especulativa por algumas personalidades excepcionais, constitui o seu capital pessoal." (9)

4. Mas o que mais distingue o artesão da Idade Média do seu sucessor - o empresário capitalista - é a motivação que o faz agir. Ao menos na opinião (contestada) do já citado SOMBART, o elemento propulsor das atividades produtivas da Idade Média é o que êle chama de "idéia de alimentação". Diz êle: "No fundo do seu coração, nada é mais estranho ao comerciante do que o desejo do lucro no sentido do empresariado moderno; assim, êle não pretende, nada mais e nada menos, do que ganhar, bem ou mal, a sua subsistência". (10)

Podemos disso concluir que, na Idade Média, o comércio exerce uma função meramente complementar à produção, pois o artesanato pouco se preocupa em granjear mercados localizados além do seu alcance imediato, seja porque o espírito

(9) Werner Sombart, Der Moderne Kapitalismus, Verlag von Duncker \& Humblot, München und Leipzig, vol. I/1, 1928, pág. 190.

(10) Op. cit., pág. 291. 
conquistador do "capitalista" lhe é desconhecido, seja porque a atividade mercantil continua a ser mal vista pelo clero e pela nobreza.

\section{O Nascimento do Capitalismo e a Expansão dos Mercados}

A época que abrange a passagem do século 15 ao século 16 traz consigo uma profunda alteração na vida social da Europa. No setor político formam-se os estados modernos, no setor econômico surge a emprêsa capitalista. A criação desta é favorecida pela descoberta de novos mercados (Oriente e Américas), pelo vasto abastecimento de matérias-primas e metais preciosos, pela invenção de processos de produção (alto-forno), pelo desenvolvimento da contabilidade em dupla partida, pela tormação de mercados organizados (A Bôlsa de Antuérpia) e pela expansão dos serviços postais em âmbito internacional.

Por sua vez, o século 17 contribui decisivamente ao fortalecimento do Capitalismo. Os seus traços principais são o aparecimento de um espírito empresarial (fomentado pelas perseguições religiosas e pela filosofia comercial dos puritanos), a expansão do mercantilismo, as inovações técnicas (sobretudo na indústria têxtil), o aumento das fortunas burguesas, a criação de sociedades por cotas, de bancos comerciais e da imprensa, como meios de concentração e divulgação de riqueza. (11)

Entre as muitas transformações radicais que o capitalismo introduz no sistema econômico das nações, figura a dissolução das quatro citadas características que determinaram a relação entre produção e comércio na Idade Média. Os mercados se expandem, inicialmente além das áreas urbanas, posteriormente além das fronteiras nacionais. O produtor perde o contato direto com o consumidor e é obrigado a procurar intermediários varejistas $e$ atacadistas. Quantidades crescentes de bens são vendidas em feiras, estabelecimentos lojistas, mercados bolsistas e até pelo correio. A expansão das emprêsas e o aumento das funções administrativas obrigam a uma

(11) Para uma análise minuciosa dos primeiros dois séculos do capitalismo, vide Sombart, op. cit., vol. II/1. 
separação entre as responsabilidades de produção e de vendas dentro das próprias organizações.

Finalmente e acima de tudo, um novo espírito começa a dominar o empresário : o desejo de auferir e aumentar o lucro, de expandir as suas atividades empresariais e entrar em franca competição com os seus concorrentes. Em consequiência, a relação entre quantidades oferecidas e procuradas se altera nitidamente. O consumidor começa a ter alguma liberdade de escolha entre maior variedade de bens e torna-se ciente dêsse privilégio. Por enquanto, contudo, essa liberdade se restringe a um grupo limitado de bens, sobretudo aos bens de luxo (obras de arte, vestimentas caras, residências feudais etc.) que, de um lado, permitem uma individualização e, pelo outro, são acessiveis à restrita camada social (sobretudo à nobreza) que dispõe de uma renda elevada.

Para que o mercado moderno possa constituir-se, duas condições ainda terão que ser estabelecidas: a criação e aplicação de processos tecnológicos capazes de permitir a produção em larga escala e uma distribuição da renda nacional de dar vazão aos bens produzidos em massa.

\section{A Revolução Industrial e o Mercado Vendedor}

A primeira destas duas condições é cumprida inesperada e radicalmente durante a segunda parte do século 18, quando uma série de invenções técnicas abre caminho à industrialização e ao transporte coletivo. As consequiências desta "maior das modificações na história humana", na opinião de TAUSSIG, foram, mais tarde, rotuladas de "Revolução Industrial".

"A característica econômica fundamental (da revolução industrial) reside na realização da divisão do trabalho por meio da dissecação dos estágios da produção em operações separadas, cada uma das quais é repetida contìnuamente, tornando possível a sua execução por máquinas." (12) As vantagens econômicas da divisão do trabalho decorrem, em es-

(12) F. W. Taussig, Principles of Economics, The Macmillan Company, New York, 1923, vol. 1, 3.* edição, păg. 35. 
sência, de duas fontes: do melhor aproveitamento das fôrças naturais (sobretudo da água, do vapor e do carvão) e da combinação racional dos fatôres de produção. Em conseqüência, quantidades crescentes de bens podem ser produzidas (e transportadas) a custos unitários decrescentes.

Uma vez que êste processo se reproduz e acumula quase que automàticamente, também o mercado se transforma. Acima de tudo, a separação entre produtor e consumidor torna-se definitiva. Em outras palavras, a produção por encomenda $\dot{e}$ progressivamente substituida pela produção especulativa, em que o fabricante produz sem ter a certeza se o consumidor deseja ou não os seus produtos e em que quantidades. Nos séculos 18 e 19 esta tendência é francamente acelerada por dois fatôres: a aceitação do papel-moeda como unidade corrente de troca e a expansão do sistema de créditos bancários.

Entre os múltiplos problemas que o administrador capitalista enfrenta durante esta fase de transição, surge a necessidade de reduzir o seu risco de não-venda face à falta de contato direto com o mercado consumidor. A maneira pela qual êle procura resolver êste problema consiste, inicialmente, no fortalecimento das vias de distribuição. Por conseguinte, "no decorrer do século 18, o comerciante por atacado se separa definitivamente dos varejistas e forma uma camada específica da organização mercantil". (13) As técnicas prediletas do atacadista são: o leilão de mercadorias em bôlsas organizadas, o comércio à base de amostras, a consignação de mercadorias a terceiros (sobretudo no comércio exterior) e a utilização comercial do correio postal.

Excetuando-se as crises de adaptação (desempregos em massa, sobretudo na Inglaterra), a revolução industrial e o liberalismo econômico que a acompanha trouxeram vários decênios de prosperidade. Nunca antes e nunca depois o capitalismo floresceu tanto e tão ràpidamente.

Para o nosso tema da transição, o que mais importa, nesta época de franco capitalismo, é o domínio do mercado pelo

(13) Weber, op. cit., pág. 249. 
fabricante. (14) A primeira vista isso soa estranho, pois seria de se esperar que o rápido crescimento industrial provocasse antes a superprodução. Todavia, as inovações técnicas trazem consigo não só novas e melhoradas condições de fabricação, como também novas oportunidades de compra e venda, sobretudo em praças distantes dos centros industriais, que antes mal podiam ser atingidas devido à dificuldade de transportes e comunicações. Além do mais, durante o período em questão, o potencial de compra recebe um duplo impulso, ocasionado pelo aumento abundante da população (15) e pelo enriquecimento daquela camada da classe média que está ligada ao financiamento e à distribuição dos produtos manufaturados em série. Por conseguinte, na média dos anos, a procura pelos bens e serviços tende a se expandir mais ràpidamente do que a capacidade produtiva das fábricas, colocando o produtor numa situação privilegiada frente ao consumidor.

Compreende-se pois, que, numa situação tão francamente favorável ao produtor, as funções da distribuição sejam relegadas a um segundo plano dentro da organização empresarial. É o que se verifica ainda no século 19: de todos os administradores de cúpula, o executivo responsável pelas vendas é quem menos influência exerce na emprêsa e menor voz tem nas decisões administrativas. Além do mais, o homem ligado ao comércio continua a ser visto com maus olhos, carregando sôbre si o pêso de um preconceito social. (16)

(14) Sombart, op. cit., vol. II/1, pág. 190 e seguintes.

(15) Este fato levou Th. R. Malthus a escrever a sua famosa obra clássica Essay on the Principles of Population (1798) que, durante vários decênios, causou agitação devido aos seus traços «pessimistas» sôbre os efeitos da superpopulação.

(16) Richard Ehremburg, em seu artigo intitulado «Handel» no Handwörterbuch der Staatswissenschaften, Verlag von Gustav Fischer, Jena, 1923, Volume 5, 4." edição, pág. 23 e seguintes, demonstrou que êsse preconceito contra o comércio sobreviveu até 0 nosso século. 


\section{Crises de Adaptação e Reivindicações Sociais}

Até aproximadamente os fins da primeira metade do século 19 , a defasagem entre quantidades procuradas e oferecidas nos mercados conduz a uma confiança quase que irrestrita no sistema capitalista e estimula o processo especulativo da produção. O emprêgo de capitais alheios para financiar programas de expansão torna-se comum e aumenta os riscos do empresário. Ao mesmo tempo, cresce a separação entre o produtor e o consumidor, acelerada pela reação conjunta da concentração de grupos empresariais e da ampliação geográfica dos mercados. Por conseguinte, o capitalismo vê-se ameaçado por dois males por êle mesmo gerados: o superinvestimento e a perda de contrôle do mercado. Todavia, uma sequiência de crises econômicas consegue salvar o sistema do colapso, porque elimina a emprêsa marginal do processo de produção.

Ao mesmo tempo, porém, surge uma nova fôrça que ameaça a estrutura capitalista : o despertar da consciência social dos assalariados, que demandam uma participação nos benefícios que o sistema concentrou na mão de uma minoria. Ansioso por conservar o "status quo" e como medida de autodefesa na luta entre concorrentes, o empresário resiste tenazmente à essas reivindicações, prejudicando a sua própria classe, que poderia ter-se beneficiado de uma redistribuição da renda nacional e da ampliação dos mercados de consumo.

Nesta situação, o intervencionismo estatal se revela como "anjo-da-guarda" do sistema de livre iniciativa, ainda que isto possa parecer absurdo à primeira vista. No entanto, não foram os movimentos trabalhistas que provocaram uma repartição mais equiitativa da renda, mas antes a legislação social imposta às emprêsas pelo estado democrático moderno, muitas vêzes com fito exclusivamente fiscal. Porém, a intenção aqui pouco importa; o que vale é o reşultado e êste favoreceu a emprêsa, sempre que esta se viu ameaçada pelas conseqüências do baixo poder aquisitivo das massas populares. 


\section{A Alvorada da Mercadologia}

E neste ambiente de fomentação e resistência social que surge o novo conceito de vendas que, mais tarde, toma o nome de "marketing". Ao descobrir que uma acentuada consciência social se desenvolve na classe média e no proletariado, alguns pioneiros da Mercadologia procuram encontrar meios mais eficazes de conquistar a simpatia da grande massa de consumidores em potencial. Os vendedores recebem instruções mais precisas, para evitar que se tornem meros tomadores de pedidos. E, para destacar as qualidades dos seus produtos, alguns empresários começam a utilizar a propagan$\mathrm{da}$, a embalagem, a rotulagem e a marca, como instrumentos promocionais.

Assim, transforma-se a atitude do empresário frente ao mercado, até o ponto de se considerar o consumidor um "rei", cujos desejos e preferências devem ser satisfeitos, inclusive à custa de sacrifícios temporários. A importância de uma renda nacional amplamente distribuída, tanto no sentido pessoal quanto no geográfico, é gradualmente reconhecida. A oposição contra a legislação social se transforma numa atitude de expectativa e, às vêzes, até de apoio ponderado.

Os empresários mais perspicazes introduzem programas ambiciosos e dispendiosos de assistência social, firmados na noção de que um trabalhador sadio, satisfeito e bem preparado produz mais a menores custos e de que uma comunidade próspera e bem acomodada constitui um bom mercado, tanto trabalhista quanto consumidor. Com êste critério de autodefesa e a indulgência social do "viver e deixar viver" em mente, o administrador moderno forja novas armas de penetração psicológica no campo das relações humanas, relações públicas e relações industriais.

Paralelo a êste processo de transformação de atitudes, corre um movimento interno nas emprêsas que visa a adaptação estrutural da organização às novas tendências. $O$ principal beneficiado dêste movimento é o administrador de vendas, que assume uma posição de reconhecida responsabilidade $\mathrm{e}$ 
autoridade. A função distribuidora de bens e serviços é aceita como parte integrante do processo econômico total, em que a produção cria a utilidade de forma, e a distribuição as utilidades de tempo, local e propriedade. Socialmente, o comerciante se libera do estigma da improdutividade e se transforma num administrador com poderes de decisão.

\section{A Interferência do Produtor no Mercado}

O fato de surgir o conceito da Mercadologia nos Estados Unidos da América é sintomático da liderança econômica e política que êsse país assume desde a primeira guerra mundial em diante. Enquanto as grandes emprêsas européias procuram conservar as suas posições no mercado por meio de fusões, cartéis e trustes, o administrador americano adota uma diretriz bem mais sadia e duradoura de autodefesa: a de criar mercados novos. Evidentemente, o clima lhe é bastante favorável, dado o vasto potencial geográfico e humano à sua disposição.

Não cremos ser exagêro afirmar que os Estados Unidos se tornaram os legítimos herdeiros da revolução industrial, quando colocaram as grandes invenções do século 19 a serviço de sua economia, por meio de um engenhoso sistema de integração entre produção e distribuição em massa.

Dêsse sistema resultou um novo tipo de produto que hoje domina os mercados de consumo da maior parte do mundo: o artigo altamente padronizado, de preço baixo e resistência limitada, acessível a um grande número de compradores.

Porém, não é da noite para o dia que o novo tipo de produto consegue firmar a sua posição no mercado. Antes, várias barreiras têm que ser sobrepujadas, a principal sendo a resistência do atacadista que, nas primeiras décadas do nosso século, pràticamente controla a distribuição de bens e se opõe à introdução de novas técnicas de venda.

Após a primeira guerra mundial, muitos empresários norteamericanos percebem a sua posição precária diante do desequilíbrio entre a alta capacidade instalada das fábricas e o 
limitado poder aquisitivo da população. Ao mesmo tempo, verifica-se que o sistema de distribuição em vigor se tornou bastante inadequado para fazer face às novas responsabilidades de promoção e criação de mercados em massa. A essa altura, os fabricantes procuram intercalar-se na esfera do intermediário, com o intuito de reconquistar o contato com o consumidor e de exercer um contrôle direto sôbre as vendas.

Trava-se uma luta aberta entre fabricantes e atacadistas, que até hoje continua acesa.

Nessa luta, a Mercadologia firma a sua posição no campo da atividade administrativa. PHELPS expressa isso quando afirma que "de tôdas as tendências históricas no campo da mercadização, nenhuma outra é tão distintamente nítida quanto a tendência do fabricante de assumir maior contrôle sôbre a distribuição de seu produto." (17)

\section{O Esfôrço de Adaptação aos Mercados}

o problema imediato que se apresenta ao fabricante é o de caracterização do seu produto, a fim de diferenciá-lo de outros produtos concorrentes. Inicialmente, a maioria dos produtores procura resolver êsse problema por meio da intensificação da propaganda, frequientemente para descobrir que esta só produz vendas, se acompanhada de outras medidas mercadológicas como, por exemplo, da investigação criteriosa das características dos mercados a serem conquistados. Isto os leva ao estudo econômico e, posteriormente, psicológico do consumo, e à adaptação dos meios publicitários à procura. Desta forma, a propaganda deixa de ser um mero instrumento auxiliar de vendas, para ocupar a dinâmica posição de criadora de mercados, abrindo o caminho ao publicitário.

Simultâneamente, o próprio produto sofre uma modificação, ditada menos pelos avanços tecnológicos do que pelas condições do mercado. Maior atenção é dedicada à marca, com a sua dupla função de protetora legal e de símbolo de distin-

(17) D. M. Phelps, Sales Management, Policies and Procedures, Richard D. Irwin, Inc., Homewood, Ill., 1953, pág. 16 . 
ção e qualidade. Desenvolvem-se as artes da embalagem e da rotulagem, que também criam uma nova profissão: a do desenhista (ou projetista industrial).

Para poder administrar os novos instrumentos mercadológi$\cos$ e, ao mesmo tempo, intensificar o seu contrôle sôbre o mercado, o fabricante vê-se obrigado a modificar também a sua estrutura interna de vendas. Em conseqüência, são reexaminadas as formas de determinação de preços e de descontos, e a organização de vendas é adaptada às novas condiçōes. O vendedor passa a ocupar uma posição de maior destaque na emprêsa, recebendo treinamento mais adequado $\mathrm{e}$ melhor bagagem de material e conhecimento de promoção. Acima de tudo, porém, ao próprio encarregado da organização de vendas, antes um mero agente entre produtor e comprador, delegam-se poderes de decisão e execução administrativa. Cabe a êle encontrar os melhores meios de integração entre as condições internas e externas da emprêsa, o que vem obrigá-lo a antecipar e planejar os acontecimentos. $\mathrm{O}$ orçamento de vendas deixa de ser um pormenor da contabilidade de custos ou do cálculo financeiro geral, para passar a exercer uma função autônoma em que a distribuição de contas e verbas é discutida à luz da eficiência e produtividade industrial e mercadológica.

A difícil tarefa de previsão de vendas também é delegada ao administrador mercadológico. Para poder cumpri-la, êste é obrigado a adquirir conhecimentos alheios à sua função direta de vendas, ou seja, conhecimentos de natureza econômica, estatística, legal, financeira, social e, às vêzes, até de engenharia industrial.

A fim de fazer face a esta multiplicidade de funçóes e para poder tornar suas decisões mais seguras, o mercadólogo se interessa por contratar os serviços de especialistas. Além do agente publicitário, beneficiam-se desta tendência sobretudo o consultor administrativo e o pesquisador de mercado. E principalmente com a crescente aceitação da pesquisa de mercado que a Mercadologia se aproxima de uma atividade com traços 
científicos, o que abre novas perspectivas para a administração moderna.

No decorrer dos anos, o contínuo esfôrço de reconquista dos mercados trouxe resultados bastante satisfatórios ao industrial norte-americano e bastante preocupação ao atacadista. De acôrdo com uma estimativa de R. S. ALEXANDER, da totalidade dos bens vendidos por varejistas americanos em 1929, $53,4 \%$ tinham sido supridos por atacadistas; desde então essa percentagem caiu até atingir $38,4 \%$ em 1954. Nos mesmos anos, a cada varejista correspondiam, respectivamente, 83,2 e 94,1 habitantes, o que indica o crescimento das lojas, cujas vendas médias anuais ( $j a ́$ deflacionadas) aumentaram de $\$ 45.000$ por estabelecimento em 1929 para $\$ 85.000$ em 1954. (18)

E interessante observar que uma tendência bem semelhante pode ser constatada no Brasil de hoje. Também os nossos industriais estão procurando anular $o$ atacadista do processo de distribuição, dirigindo-se diretamente ao varejista ou organizando as suas próprias cadeias de lojas diretamente supridas pelas fábricas. No Brasil, um dos fatôres que mais aceleram êsse processo é a reincidência do impôsto de vendas e consignações, além dos motivos ocasionados pelo crescimento das emprêsas e mercados, do desejo de um contrôle mais direto, da insatisfação com o atacadista e outros.

\section{$O$ "Espírito Seletivo" e as Economias em Expansão}

De caráter algo especulativo, mas, nem por isso, menos fascinante, é a pergunta sôbre a futura posição do administrador mercadológico na emprêsa. Da sua resposta depende, em grande parte, o progresso da Mercadologia, não só como instrumento administrativo, mas também como campo de estudo, e a sua eventual integração no corpo das ciências sociais.

(18) Ralph S. Alexander, The Changing Structure of Intermediate Markets and Manufacturers' Marketing Strategy, in «Changing Structure and Strategy in Marketing», Robert V. Mitchell (editôres), University of Illinois Bulletin, Urbana, Ill., maio 1958, págs. 68 e 71. 
Devido a seus objetivos essencialmente práticos, a Mercadologia desenvolver-se-á em função do grau de influência que o consumidor conseguir exercer sôbre o processo de decisão das emprêsas. Quanto maior fôr essa influência, tanto mais atenção o dirigente empresarial atribuirá aos problemas de distribuição e vendas e tanto mais firme será a posição do administrador mercadológico. Resta, pois, saber de que depende a influência do consumidor sôbre a emprêsa.

A experiência tem demonstrado que a emancipação do administrador mercadológico ocorreu numa época em que duas fôrças romperam simultâneamente na esfera econômica e soctal. Em primeiro lugar, verificou-se a transição do mercado vendedor a um mercado comprador, no qual a oferta global de bens veio a superar a procura, colocando o comprador na invejável posição de poder "ditar" ao fabricante o que, quanto e como devia produzir. Em segundo lugar, pôde-se observar, no passado recente, a intensificação de um fenômeno que, por falta de um têrmo melhor, chamamos de "espírito seletivo". Referimo-nos àquela atitude crítica, em relação aos produtos oferecidos no mercado, que se cria na mente do consumidor com o desenvolvirnento da sua consciência e posição social, e com o progresso da sua instrução.

Um número muito maior de pessoas está hoje apto a exercer êsse poder de escolha, e bem maior será êsse número amanhã. Isto, em parte devido à socialização das massas, em parte dado ao avanço da educação.

As próprias emprêsas contribuem, diàriamente, para alimentar o espírito seletivo, devido a sua ansiedade de conquistar parcelas sempre maiores do mercado em potencial, colocando à disposição do consumidor um vasto material informativo por meio da propaganda e da promoção de vendas. Quanto mais se intensifica êste processo, tanto mais intenso terá que ser o esfôrço da emprêsa para se adaptar aos desejos dos seus clientes, a menos que êstes se encontrem numa situação de real desvantagem econômica, como nos casos de depressão aguda ou de desemprêgo em massa. 
Podemos, disto, concluir que a existência de um mercado comprador não mais constitui condição exclusiva para tornar a adaptação aos mercados uma necessidade ou, ao menos, uma diretriz recomendável às emprêsas. E isto, por sua vez, contém uma inferência importante para as economias que, como a do Brasil, ainda não atingiram o estado pleno de orientação para o consumo: com o progresso educacional, compensa às emprêsas dedicar-se intensamente ao estudo das condições que fazem o consumidor optar por um ou por outro produto.

\section{Conclusões}

Desde que o homem descobriu as vantagens da especialização do trabalho, existe o intercâmbio de bens e serviços, inicialmente sob a forma de trocas e compensações, depois por intermédio de um comércio organizado. Houve fases na história econômica mundial em que a distribuição constituiu a principal fonte de riqueza e de prestígio social (exemplo: Veneza no século 15). Estas fases, porém, representam a exceção à regra que reserva ao processo técnico de produção o elemento criador que é negado ao comércio.

Sobretudo desde a Idade Média, a função comercial passa a ser relegada a segundo plano na hierarquia administrativa da emprêsa e, apesar do extraordinário impulso que o comércio recebe, no capitalismo, os problemas de produção continuam a dominar o pensamento empresarial nos séculos 16 a 19.

No século 20, contudo, surge uma tendência de emancipação do comércio e de seu portador, o dirigente comercial ou administrador mercadológico. Quais são as origens desta tendência, quais são as suas características e conseqüências para o administrador de hoje? Ao redor destas perguntas, gira a presente análise e interpretação.

Sob risco de simplificarmos demasiado a realidade, mas a favor da clareza de posição, passaremos a responder a essas perguntas de forma resumida e esquemática, procurando es- 
clarecer a relação existente entre determinadas inovações de ordem social ou econômica e suas consequiências para a emprêsa e o seu dirigente.

Inicialmente, convém dividir-se o movimento histórico em duas fases de características distintas: a primeira coincide com o nascimento e a evolução do capitalismo, a segunda poderá ser rotulada como "fase de fricção" (entre os sistemas capitalista e socialista).

\section{A - Fase do Capitalismo}

1. Inovação: $O$ propósito de lucro. O desejo de auferir um lucro maior que o indispensável à sobrevivência rompe a economia fechada prevalecente até o fim da Idade Média.

Conseqüência: A criação da emprêsa capitalista. Esta visa, por meio da acumulação de lucros, aumentar continuadamente o seu patrimônio, tanto pessoal quanto material.

2. Inovação: A conquista de mercados. Nos séculos 15 a 17 criam-se novas formas de comércio, como o atacado em larga escala, os bancos comerciais e as bôlsas. No âmbito internacional, a expansão leva grandes impulsos pela descoberta das Américas e do caminho marítimo ao Oriente.

Conseqüência: A separação geográfica entre produtor e consumidor. Ampliam-se as oportunidades de negócios, mas o contrôle dos mercados é dificultado.

3. Inovação: As invenções técnicas e a divisão do trabalho. A manufatura transforma-se em indústria, sobretudo desde a revolução industrial.

Conseqüência: A produção em massa. Traz consigo a espe cialização geográfica, a racionalização e a redução dos custos unitários, mas também o aumento do risco de não-venda, devido à necessidade de produzir-se para o estoque em vez de sob encomenda.

Ao conjugar êstes fatôres, podemos melhor compreender porque e como o capitalismo conseguiu manter-se, apesar do fenomenal aumento da capacidade de fabricação que se pôde 
observar nos séculos 16 a 19 . É que êste aumento foi, em média, acompanhado por uma expansão mais do que proporcional da procura de bens, ocasionada pela reação conjunta do incremento da população, do poder aquisitivo e da conquista de mercados externos. Nas poucas épocas em que a oferta global de bens superou a procura (aos preços vigentes), crises econômicas provocaram a eliminação dos produtores marginais, abrindo, assim, caminho a novas expansões. A predominância do mercado vendedor é, pois, uma característica secular da economia capitalista e constitui, ao mesmo tempo, a explicação do modesto "status" social que o encarregado do setor de vendas ocupa na emprêsa capitalista.

Podemos, de tudo isso, concluir que o capitalismo criou as condições técnicas, mas não o ambiente econômico essencial à emancipação do comerciante.

\section{$B-$ Fase de Friç̧ão}

1. Inovação: A criação de produtos padronizados. É uma decorrência da produção em massa, sobretudo desde que a linha de montagem e, mais tarde os processos de automação permitem (e freqüentemente exigem) uma fabricação de bens a custos e preços reduzidos, acessíveis a um grande número de compradores e sem características físicas substanciais que permitam a distinção de produtos concorrentes.

Conseqüência: A necessidade de diferenciação. A padronização física obriga cada produtor a criar condições que tornem o seu produto distinto dos produtos concorrentes, seja por meio da diferenciação do próprio produto (marca, embalagem, rotulagem, modêlo, côr, capacidade etc.), seja pela maneira de mercadizá-lo (vias de distribuição, ambiente, promoção ou satisfação de após-compra).

2. Inovação: A transição para o mercado comprador. Com a expansão industrial, a perda de contato direto com o freguês e a necessidade de se produzirem quantidades substanciais para o estoque, a oferta global de bens tende a superar a sua procura. 
Consequiência: A necessidade de conquistar novos mercados. Sendo baixas as margens de lucro por unidade e altos os custos fixos da produção em massa, a concorrência de preços torna-se limitada. A sobrevivência ou expansão da produção depende da conquista de novas oportunidades de venda, tanto em extensāo geográfica, quanto por meio de inovaçōes e, mais tarde, pela criação de obsolescência prematura.

3. Inovação: O despertar do "espírito seletivo". Devido à consciência social e ao progresso da educação, um maior número de indivíduos torna-se capaz de escolher mais criteriosamente entre os produtos oferecidos na praça.

Conseqüência: A necessidade de orientar as decisões administrativas de acôrdo com as condições do mercado. 0 crescente conhecimento de causa do consumidor e a sua atitude sempre mais crítica face ao produto obrigam a emprêsa a tomar decisões de produção e distribuição baseadas nas preferências e nos desejos do comprador.

Cada um dos três fatôres acima mencionados seria suficiente para modificar a estrutura de uma emprêsa. Conjugados os fatôres, o impacto terá que ser maior ainda, pois as três fôrças agem em sentido idêntico, privando a emprêsa da sua autonomia da decisão. Nestas condições, a emprêsa vê-se obrigada a adaptar as suas fôrças internas e controláveis (ou seja, o produto e a organização) às fôrças externas vigentes no mercado.

Éste processo de adaptação exige do dirigente empresarial um esfôrço que ultrapassa as funções tradicionais do comerciante. Obriga-o a tomar a si as rédeas da decisão e tornar-se um administrador mercadológico. 